\title{
AMARAL, Celena Izabel do. Representacões do Feminino e Masculino \\ nas Estórias Infantis. Curitiba: Mestrado em Sociologia da UFPR, 2004, $196 \mathrm{p}^{1}$.
}

Isaura Maria Rigitano de Limas ${ }^{2}$

- Enviado em 15/05/2016

- Aprovado em 18/06/2016

O estudo Representações do Feminino e Masculino nas Estórias Infantis de Celena Izabel do Amaral, produto final de sua dissertação para a obtenção do título de mestre em Sociologia pela Universidade Federal do Paraná, aborda uma problemática atual mas que sempre esteve presente nas escolas brasileiras: a representação sexista do padrão binário entre os gêneros que ocupam as esferas públicas e privadas.

A pesquisa foi elaborada através da análise e mapeamento das representações de gênero nas linguagens escrita e ilustrativa produzidas em quarenta e quatro estórias infantis contemporâneas, veiculadas em uma turma de $3^{\circ}$ série do ensino fundamental de uma escola particular em Curitiba no final do século XX. Foi escolhida uma turma com um número equilibrado de meninos e meninas da faixa etária entre 8 e 10 anos. Na fase quantitativa foram utilizados listagens, quadros e tabelas e o conteúdo revelado foi analisado pelo seu contexto literário e depois classificado, tabulado e codificado. Amaral propôs verificar se os padrões de comportamento social tradicionais entre gêneros são reproduzidos pelas estórias e como esse material é visto e trabalhado em sala. Também,

\footnotetext{
${ }^{1}$ Dissertação de Mestrado em Sociologia defendida no Programa de Pós-graduação em Sociologia da UFPR no ano de 2004 realizado sob a orientação da Professora Doutora Maria Tarcisa Silva Bega.

${ }^{2}$ Isaura Maria Rigitano de Limas é bacharel e licenciada em Dança pela PUC-PR. Professora da ESL e tradutora. Endereço eletrônico: irigitano@ hotmail.com.
} 
através do material analisado, buscou saber em que proporção a associação de desigualdade de poder social está relacionada ao binarismo de gênero.

A pesquisa parte de uma série de questões de ordem prática: que tipo de representação de feminino e masculino uma criança de oito anos pode ter através de uma estória onde a diferença nos gêneros masculino e feminino reflete em uma diferença de poder e prestígio? Como a escola trabalha com tais representações? De forma consciente ou inconsciente? Reafirmando seu conteúdo, ou não? E qual é o peso dessa literatura na formação dos papeis sociais das crianças, independente do tipo de educação que foi dada em casa pelos pais. Essas são questões de extrema importância no intuito de almejar o maior entendimento e aceitação no panorama social atual, onde a desigualdade se faz muito presente.

É sabido que a criança tem na escola, em seu processo de crescimento e aprendizagem, uma fonte importante na obtenção dos valores morais e sociais que irão perpetuar em sua formação como indivíduo. A literatura infantil está inserida no conteúdo curricular obrigatório como parte dos meios de formação e é utilizada no ensino da aquisição da gramática e no estudo da língua em si. Por essa razão ela atua como auxiliar reprodutor da visão social, sendo que é na primeira infância que as crianças fixam melhor o aprendizado através do lúdico. Por sua condição de desenvolvimento intelectual, as crianças só são capazes de entender e processar um conteúdo de forma hipotética ou dedutiva no início da adolescência, por volta dos 12 anos. A literatura infantil trabalha portanto, como um agente de formação.

Em um primeiro momento observou-se como as representações sociais de gênero estavam presentes no material paradidático das crianças, no ambiente físico, no material de ensino e no próprio comportamento dos educadores. A partir dessa observação, como objetivo especifico, buscou-se identificar se as relações sociais entre os gêneros feminino/masculino reproduziam padrões sexistas onde o papel feminino está em uma posição subalterna, com menor visibilidade e poder social, e o masculino, independentemente de qual vínculo de dependência, está sempre em uma posição de poder.

A pesquisa foi dividida em quatro capítulos. No primeiro capítulo para a fundamentação teórica foram citados vários autores, contudo percebe-se maior influência do filósofo francês Pierre Bourdieu (1930-2002), que melhor trabalhou em termos pedagógicos a questão da dominação e tem um extenso trabalho na área da educação, onde desenvolveu estudos para demonstrar as estratégias e os mecanismos de reprodução cultural e social em diferentes agentes e grupos sociais. 
No segundo capítulo foi feito um detalhamento da etapas da realização da pesquisa e os agrupamentos das representações de gênero, nas linguagens escrita e ilustrativa produzidas em quarenta e quatro estórias infantis contemporâneas, publicadas em quase toda a sua totalidade nas décadas de 80 e 90.

No terceiro capítulo a autora mapeou e agrupou as atividades exercidas pelos gêneros masculino e feminino nos espaços público e privado nas estórias. Percebeu se, a partir daí, que é atribuído ao feminino uma posição social inferior e consequentemente ao masculino, uma posição social de poder e prestígio.

O quarto capítulo mostra a proporção da autoria feminina e masculina nas estórias e nas ilustrações, a distribuição desigual de poder entre os gêneros e a características vinculadas ao gêneros. A autora explica que não tem o propósito de levantar bandeiras, mas sim de fomentar a visão crítica sobre temas que, muitas vezes por serem vistos isoladamente, passam desapercebidos. Por existir uma falta de consenso entre teóricos da área da educação sobre esse tema, fez-se necessária uma abordagem teórica sobre o início da literatura infantil.

A literatura infantil começa a aparecer com a ascensão da família burguesa na Europa, no século XVII. Chapeuzinho Vermelho, de Perrault (1697) é um bom exemplo dentre tantos outros contos trazidos da idade média que foram adaptados e reescritos. A infância, antes da ascensão da burguesia, era vista como um período intermediário, onde o pequeno ser não tinha capacidade nem autonomia perante os adultos. A própria definição da palavra infância, do latim infantia, significa incapacidade de falar. Com o início da prática pedagógica nas escolas e com a elevação da infância a um status social, surge uma nova configuração de família, e a arte literária infantil ganha peso para atender aos interesses pedagógicos burgueses de reproduzir uma arte moralizante.

No Brasil, segundo a autora, os primeiros contos que se tem registro são encontrados entre o fim do século XIX e início do século XX, ou seja , bem depois do que na Europa. A exemplo o livro Contos da Carochinha de Alberto Figueiredo Pimentel (1894), que também busca um sentido socializador. Estórias datadas dessa época dão destaque à virtude e à honestidade. Imbuem-se da moral burguesa e ensinam que a verdadeira felicidade está na virtude, e que somente em um lar feliz, onde a mulher santa e pura rege, a alegria de uma vida honesta é encontrada.

No início do século XX surge a onda nacionalista, figurada pela Semana de Arte Moderna de 22. Os contos de fadas, adaptados da idade média e que incitavam o leitor à fantasia são substituídos por histórias do folclore brasileiro, exaltando lendas nacionais e mostrando o 
extraordinário como parte do real. A exemplo do livro Narizinho Arrebitado (1921) de Monteiro Lobato, um dos mais influentes autores brasileiros de todos os tempos. Suas estórias povoaram e povoam o imaginário de várias gerações de brasileiros.

A literatura na década de 30 é marcada pelo antagonismo entre realismo e fantasia. Em 40 inicia-se a expansão da literatura em quadrinhos e também é estabelecida educação pragmática, onde as fadas, as bruxas, os príncipes e as princesas dão espaço à narrativa do cotidiano. As estórias dão grande importância à formação do cidadão em função do progresso e da unidade nacional. Em 50 inicia a era televisiva e com ela a crise da leitura. Começaram a ser desenvolvidos projetos de teatro para crianças, na televisão. Os anos 60 no Brasil foram de transição. Apesar da repressão, da ditadura militar, da censura e violência, também foi a década de maior expansão cultural, com o tropicalismo e a jovem guarda. Na literatura, os currículos para o ensino de $1^{\circ}$ e $2^{\circ}$ graus começaram a ser padronizados e o texto literário passou a servir de ponto inicial para o estudo de gramática e da língua portuguesa.

Mas é entre os anos 70 e 80 que acontece uma grande produção no campo da literatura infanto-juvenil. Como traços dessa explosão criativa surgiram conceitos como o experimentalismo, a estruturação da narrativa, o questionamento dos valores e o visual do texto, colocando a ilustração em destaque, com igual ou até maior importância do que o texto. Infelizmente o sistema de ensino nessa época foi deficitário e não acompanhou a expansão da literatura. As produções literárias trouxeram três tendências principais: a realista, a fantasista e a híbrida.

Os livros paradidáticos começaram então a servir de suporte para as práticas político ideológicas. Passou a ser necessário um acompanhamento para classificar e identificar essas obras, pois elas serviriam de auxílio importante na formação dos alicerces do futuro cidadão. Mas infelizmente, segundo a autora, apesar da grande importância da literatura infantil na sociedade, ela foi e ainda é muito pouco percebida, analisada e criticada.

A literatura é uma forma de representação social, e assim sendo, espelha a realidade conforme um grupo social especifico. Amaral acredita na validação dessa abordagem porque tanto os adultos como autores das estórias se representam enquanto inseridos em um contexto histórico social, as crianças através das mesmas estórias se tornam receptoras e reprodutoras dessas representações. E essas representações, como herança social que se interpõe nas relações sociais, é o que a autora lança mão para o estudo teórico de gênero. 
As lutas igualitárias ganham corpo a partir da década de 60, e com elas a segunda onda do feminismo. A construção social sobre as mulheres ainda não tinha sido explicada e estudada teoricamente até então. Nos anos 70 foram estabelecidos estudos sobre os papéis desempenhados pelos homens e mulheres como resultado de construções sociais, e não propriamente relacionados ao sexo, ao biológico. A autora faz correlação entre vários autores, mas parte de Bourdieu, que explica que o sexismo faz a discriminação de um dos sexos atribuindo funções e papeis diferentes a eles, e que essa construção social milenar causa um efeito tanto nos corpos quanto nas mentes dos indivíduos. Dada à constância, leva os indivíduos a internalizarem essa construção social, a legitimando inconscientemente. É o que entendemos como hábito, ou habitus, um sistema de disposições que as pessoas obtém via socialização. E segundo Bourdieu, inverte-se a relação entre dominador e dominado, produzindo um habitus específico, tornando a possibilidade da transgressão algo impensável. Portanto, a visão natural da condição feminina denuncia seu lugar de inferioridade atribuído socialmente.

Duas teorias de pólos opostos se sobressaem nas décadas de 70 e 80 . Na visão diferencialista, vale-se da biologia para justificar que as mulheres negaram suas essências, destituindo-se de sua identidade. Na teoria construtivista, o gênero é construído socialmente, e não determinado pela biologia. Mas foi com o pós-estruturalismo, marcado pela desconstrução das dicotomias, onde é possível incluir diversas formas de masculinidade/feminilidade geradas socialmente.Todo esse estudo se fez necessário para que se possa entender e identificar a distribuição de gênero na literatura infantil.

Destarte, a reprodução de dominação masculina ocorre e é reforçada pelas próprias mulheres porque todos somos educados a ver, a interpretar e a reproduzir o mundo baseados nas categorias do pensamento masculino. Esses padrões de pensamento estão internalizados e são legitimados inconscientemente, fazendo com que pareçam naturais, correlacionando-se à questão do poder. Independentemente da relação, o gênero masculino está sempre no pólo dominante. E o que acontece no campo da literatura infantil? Na relação de adulto/criança na literatura o adulto é o emissor e a criança o receptor e socialmente não existe um canal formal de questionamento espontâneo por parte do receptor sobre o conteúdo lido. Como só no início da adolescência, por volta dos 12 anos, é que começa o último estágio do desenvolvimento da inteligência onde acontece a reflexão completa, o raciocínio hipotético e dedutivo, até então todo pensamento se dá pela ação e realidade, isenta de teorias e questionamentos teóricos. Os valores sociais são portanto introjetados 
através da literatura infantil, existindo claramente a interferência dos adultos no desenvolvimento da criança.

A autora ressalta a extrema importância de um educador preparado como coadjuvante na transmissão de valores. Deve-se existir um estudo prévio na escolha do material a ser trabalhado em sala, para que as representações de gênero na literatura infantil não pareçam determinadas tanto para as crianças que irão ler como para os adultos educadores evitando assim impor limites em seu desenvolvimento intelectual e social. É preciso evitar padrões estereotipados onde os gêneros ocupem uma posição social marcada por um valor social correspondente. A condição da mulher passou e passa por uma profunda transformação, novos valores em torno da condição feminina se manifestaram com mais freqüência em produções literárias infantis e juvenis no início do século XXI. Mas ainda a maioria das publicações trabalhadas em sala de aula são datadas dos anos 80 e 90. Essa questão não é recente, tanto que em meados dos anos 70 foi desenvolvida uma pesquisa por equipes da Fundação Carlos Chagas denunciando na Literatura Infantil "de ontem e de hoje os valores preconceituosos da sociedade tradicional burguesa ( preconceitos raciais, discriminação das mulheres pelo preconceito machista, desrespeito à criança, etc.)."3

Portanto, a literatura infantil contribui continuamente para a assimilação da representação de gênero nos meios sociais. Tendo em vista sua importância, entende-se a necessidade de uma melhor análise e atenção no conteúdo dos conceitos repassados para o publico infantil. Percebe-se também o tamanho grau de responsabilidade inserido nessa atividade, porque o reforço ou a negação dos padrões estereotipados de gênero estarão eternizados e serão reproduzidos pelo ser em formação. Celena Amaral lança duas questões para reflexão: "O que os profissionais de educação, escritoras editoras, governantes, mães e pais, cidadãs e cidadãos querem com a insistente manutenção dessa literatura sexista?" e também: "que sociedade é essa que se diz democrática e ao mesmo tempo desrespeita as crianças e se omite diante das desigualdades voltadas às mulheres, que é complacente às distorções de suas identidades se fechando às perspectivas de uma sociedade mais humana?"4 Apesar de se considerar a imensa transformação já ocorrida nas relações sociais, essas questões ainda ecoam sem uma resposta pertinente. Talvez o futuro traga uma maior visibilidade ao estudo de gênero como parte dos estudos culturais e tais questões comecem a ser consideradas. Que

\footnotetext{
${ }^{3}$ Coelho, N.N. Literatura: arte, conhecimento e vida. São Paulo, Peirópolis, 2000, p.151.

${ }^{4}$ Amaral, Celena Izabel. Representações do Feminino e Masculino nas Estórias Infantis.Curitiba,2004,187
} 
as posições de prestigio e poder possam ser galgadas e escolhidas conforme a vontade e o esforço, independente de uma pré estipulação limitada pelo gênero. 